\title{
Seismic hazard assessment of Greenland
}

\author{
Peter Voss, Stine Kildegaard Poulsen, Sebastian Bjerregaard Simonsen and Søren Gregersen
}

Earthquake activity in Greenland has been registered and mapped since 1907 (Larsen et al. 2006) and thus a long (albeit relatively sparse) record of seismic activity is available for evaluation of seismic hazard and risk. Seismic hazard assessment is carried out by judging the probability of future earthquakes in a given region and is based on statistic treatment of earthquake data. The determination of the seismic hazard is the first step in an evaluation of seismic risk, i.e. the possible economic costs and loss of human life after an earthquake. The motivation for this seismic hazard study is the registration of four significant earthquakes in Greenland in 2005. The Geological Survey of Denmark and Greenland (GEUS) received reports of all four earthquakes from residents who had felt the shaking. The 2005 earthquakes were located at or near Qeqertarsuaq on 30 March, Sisimiut on 23 July, Station Nord on 30 August and Attu on 23 October (Fig. 1), with magnitudes on the Richter scale of 4.3, 4.1, 5.1 and 2.5, respectively. The earthquake in Attu led to the inhabitants fleeing in their boats.

\section{Earthquake activity}

Seismic hazard is just one of many natural hazards in Greenland. Other natural hazards include: continuous permafrost that constitutes a serious obstacle to development over the northern two-thirds of Greenland; strong katabatic winds that occur along the edge of the ice cap; very low wind chill and cold sea water, and; landslides and landslide-generated tsunamis (e.g. Dahl-Jensen et al. 2004). Offshore geohazards have been studied by GEUS for the 2002 licensing round off the Greenland west coast (Christiansen et al. 2002).

A first estimate of the seismic hazard of Greenland was presented during the Global Seismic Hazard Assessment Program (GSHAP; Giardini et al. 1999). For Greenland GSHAP used the very sparse data set that was collected prior to the mid-1990s. Since that time the data set has been much improved. The earthquake information used in this seismic hazard study has been extracted from the GEUS earthquake database and constitutes 227 events that occurred from November 1971 to February 2006 (Figs 1, 2). The majority of these events had a magnitude between 3.0 and 5.0, but since 2005 improved analytical methods have lowered the detection threshold from 3.0 to 1.0 in some areas. The earth- quakes were primarily shallow; $93 \%$ have been located between 0 and $40 \mathrm{~km}$ depth.

The location of the earthquakes in the GEUS earthquake database is determined primarily by using measurements from the network of permanent and temporary seismic sta-

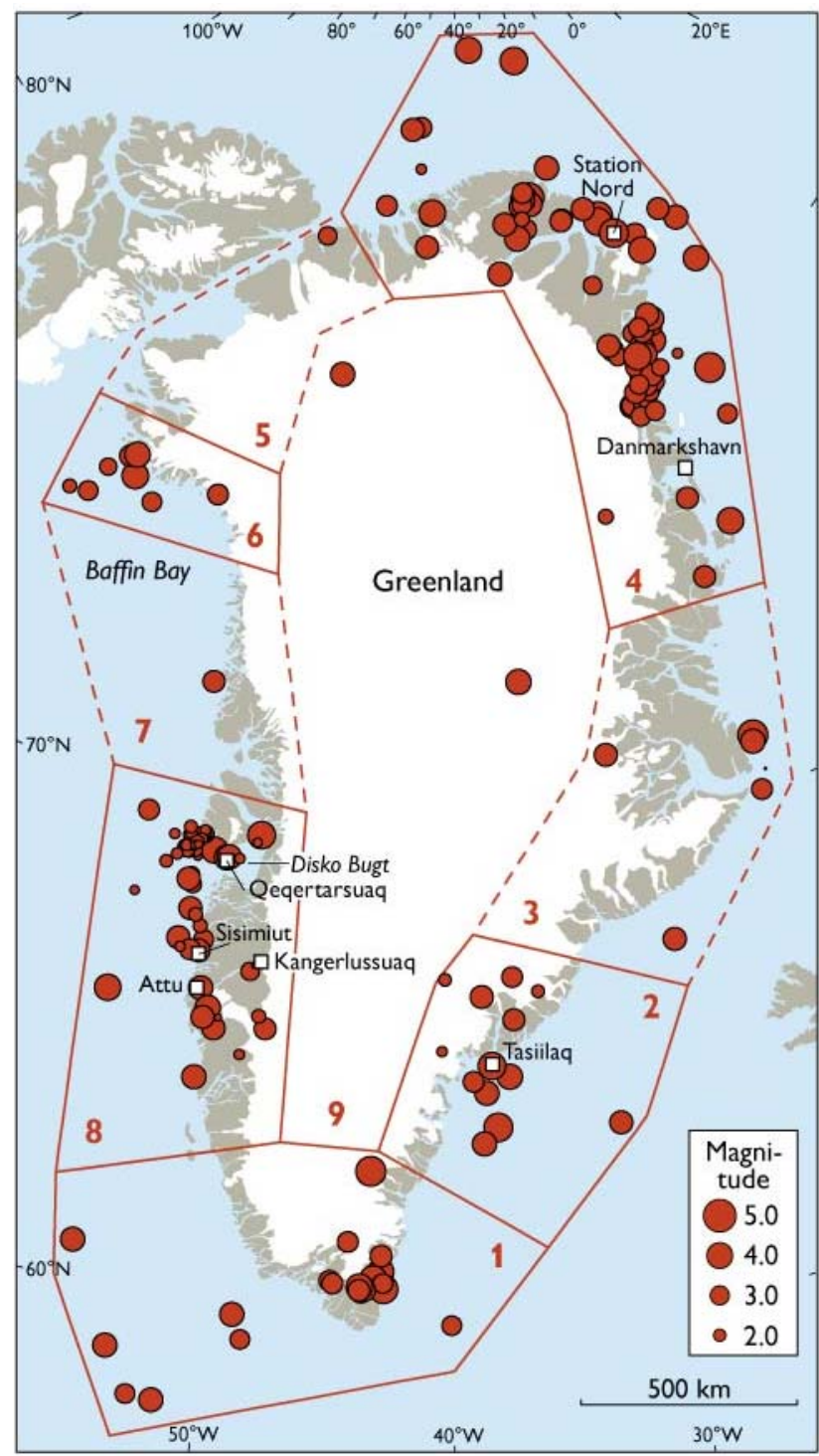

Fig. 1. Map showing the nine seismic source zones chosen for seismic hazard assessment of Greenland and the location and magnitude of earthquakes registered in the period November 1971 to February 2006 used in this study. In zones bordered by dashed lines the number of earthquakes is too low to provide input values to hazard assessment (see Table 1). 


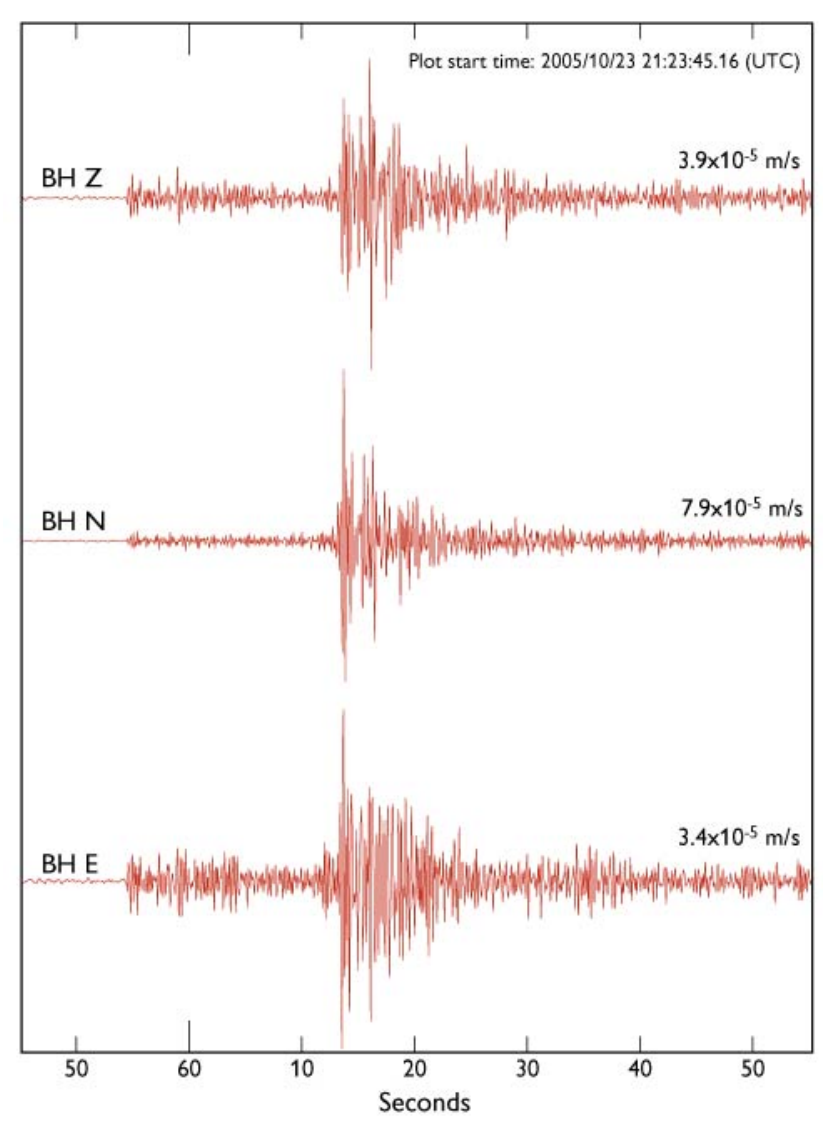

Fig. 2. Seismogram for the Richter scale 2.5 Attu earthquake on 23 October, 2005 recorded at the seismic station in Kangerlussuaq. Each trace shows the ground velocity in the direction indicated. The seismogram is band-pass filtered between 1 and $5 \mathrm{~Hz}$, and the scale of the maximum amplitude is given at the end of each trace.

tions. By the end of 2006, the network of broadband, seismic stations in Greenland included four permanent and 14 temporary stations (Larsen et al. 2006). If an earthquake in Greenland has been recorded by a seismic network in a neighbouring country, these recordings are included in the database. The neighbouring networks that have provided most data are operated by the Geological Survey of Canada, the Norwegian Seismic Array (NORSAR) and the University of Bergen, Norway.

Table 1. Input parameters used in seismic hazard computation

\begin{tabular}{ccccccc}
\hline Zone & $\begin{array}{c}\text { Number } \\
\text { of earth- } \\
\text { quakes }\end{array}$ & $\begin{array}{c}\text { Activity } \\
\text { [year }{ }^{-1}\end{array}$ & $\begin{array}{c}\text { b-value } \\
{[\mathrm{log}]}\end{array}$ & $\begin{array}{c}\text { Max. } \\
\text { expected } \\
\text { magnitude }\end{array}$ & $\begin{array}{c}\text { Max. } \\
\text { observed } \\
\text { magnitude }\end{array}$ & $\begin{array}{c}\text { Magnitude } \\
\text { threshold }\end{array}$ \\
\hline 1 & 20 & 1.062 & 2.556 & 5.5 & 5.0 & 3.7 \\
2 & 13 & 0.371 & 2.072 & 5.7 & 5.2 & 3.8 \\
3 & 6 & - & - & - & - & - \\
4 & 77 & 2.166 & 2.072 & 5.9 & 5.4 & 3.8 \\
5 & 1 & - & - & - & - & - \\
6 & 8 & 0.213 & 1.105 & 5.4 & 4.9 & 3.5 \\
7 & 1 & - & - & - & - & - \\
8 & 70 & 1.012 & 2.717 & 5.6 & 5.1 & 3.8 \\
9 & 2 & - & - & - & - & - \\
\hline
\end{tabular}

Note: Number of earthquakes in zones 3, 5, 7 and 9 is insufficient to provide input values to hazard assessment

\section{Data analysis}

The input for this seismic hazard study is the location, time and magnitude of the observed earthquakes. The location and time are determined using a 1D Earth model and an iterative linear inversion scheme (Lienert \& Havskov 1995; Havskov \& Ottemöller 2003). The magnitude used is the body wave magnitude $m_{b}$, and if that is not available, the local magnitude $M_{L}$ (Gregersen 1982). The attenuation of seismic $L_{g}$ waves is known at a few seismic stations as described by Gregersen (1982), but a full attenuation model for Greenland is at present not available. We have therefore applied the global reference model SEA96 by Spudich et al. (1997) that describes attenuation from normal faults in hardrock conditions. Focal plane solutions have been estimated for only five earthquakes in Greenland (e.g. Gregersen 2006), and have thus not been included in this study. Palaeoseismic information could be of interest if available, but has not been included since palaeoseismic data are of little influence for return periods less than 1000 years in intraplate settings (Atakan et al. 2001). Offshore reflection seismic profiles along the west coast of Greenland (Chalmers \& Pulvertaft 2001) show the presence of major fault systems that should be taken into account for return periods longer than 1000 years.

The coastal area of Greenland has been divided into eight seismic source zones that were chosen according to geological structures and the seismicity of the area (Fig. 1). The central part of the ice cap is represented by a single zone. Input values for the hazard assessment for each seismic source zone were determined from b-value and magnitude estimates (see Table 1 and Fig. 3). As an example, the computation of the b-value for seismic source zone 4 is shown in Fig. 3. The hazard computation is in the form of estimated maximum acceleration for a return period of 475 years, and is described in detail by Poulsen $\&$ Simonsen (2006).

\section{Ice cap seismic hazards}

Earthquake measurements on the Greenland ice cap have shown that the seismic energy is transmitted through the ice for both local and teleseismic earthquakes. The attenuation model we have applied to estimate the seismic hazard in Greenland is based on hard-rock conditions; thus, the approach used in this study and the results obtained do not apply for conditions on the ice cap. Ground shaking from the newly discovered glacial earthquakes, or icequakes, (Ekström et al. 2003, Larsen et al. 2006) has not been taken into account either. Only a very few earthquakes have been located below the ice cap (see Fig. 1), and seismic hazard in the interior of Greenland is therefore considered to be even lower than the lowest hazard in any coastal area. 


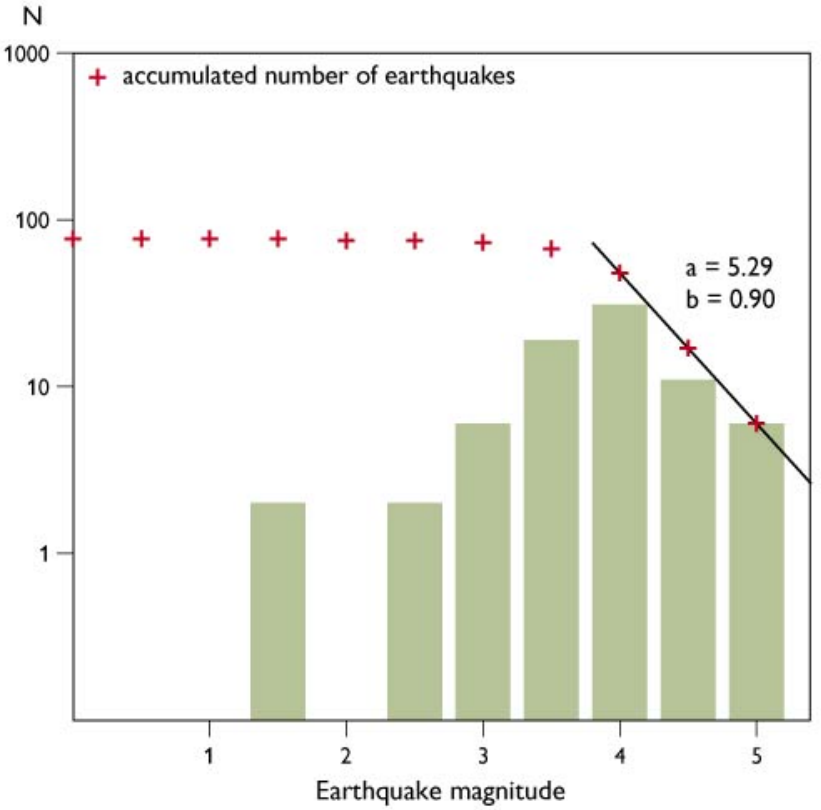

Fig. 3. Histogram showing the number and magnitude of earthquakes determined in seismic source zone 4 . It is a global experience in seismology that the number of earthquakes $(\mathrm{N})$ of various magnitudes $(\mathrm{M})$ can be expressed in a logarithmic relation: $\log \mathrm{N}=\mathrm{a}-\mathrm{b} \times \mathrm{M}$ (black line). The a-value is a measure of regional seismicity, whereas the b-value may be viewed as a regional physical constant.

\section{Seismic hazard}

The seismic hazard assessment of Greenland is computed for a return period of 475 years as shown in Fig. 4. The maximum hazard is found in seismic source zone 4 at a value of $0.051 \mathrm{~g}\left(50.37 \mathrm{~cm} / \mathrm{s}^{2}\right)$. From this result we assess the general seismic hazard in Greenland to be low, following the classification of Jiménez et al. (2003) in which low, moderate and high hazards correspond to peak ground accelerations of 0.0-0.08 g, 0.08-0.24 g and above $0.24 \mathrm{~g}$, respectively, for a 475-year return period.

Seismic source zone 4 covering the northern and northeastern parts of Greenland is the area with the highest seismic hazard; the seismic hazard is below $0.05 \mathrm{~g}$ in the other seismic source zones where the highest hazards are encountered in the Disko Bugt - Sisimiut area (seismic source zone 8) followed by southern Greenland (seismic source zone 1). These results differ considerably from the GSHAP estimates that are below $0.02 \mathrm{~g}$ for the northern and the north-eastern parts of Greenland. Along the east coast of the Baffin Bay we find the seismic hazard to be below $0.024 \mathrm{~g}$, where GSHAP reported a hazard of up to $0.08 \mathrm{~g}$.

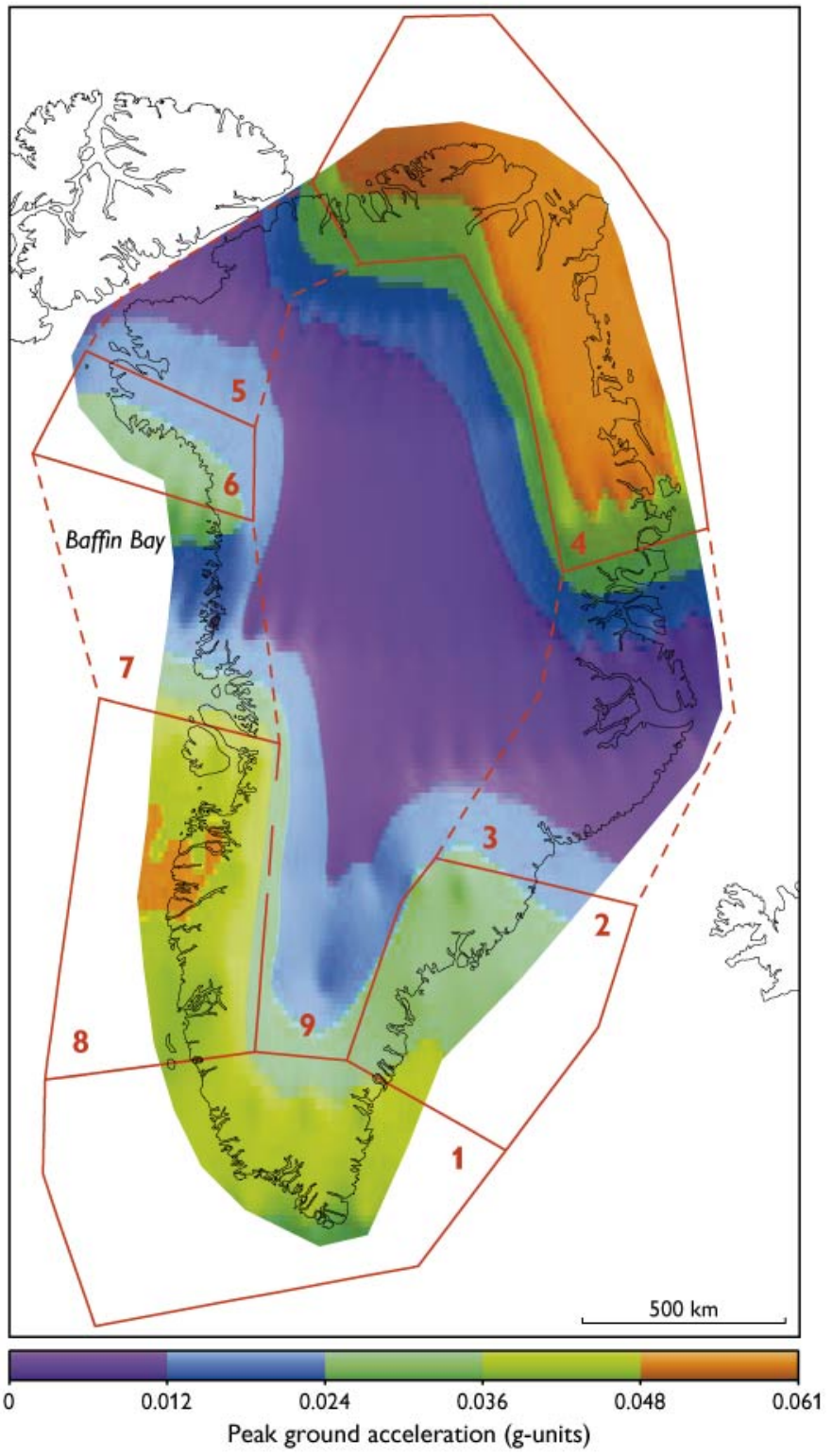

Fig. 4. Map showing seismic hazard in Greenland for a 475-year return period, corresponding to the $10 \%$ probability of exceeding a given gvalue in a 50 -year period (hard-rock conditions). Seismic source zones from Fig. 1 indicated.

\section{Seismic risk}

A full evaluation of seismic risk would include collecting indepth knowledge of factors such as infrastructure, building standards and population density distribution, work that is beyond the scope of this study. Here we outline only the expected, relative seismic risk for the four areas of highest seismic hazard. Though the highest seismic hazard is found in the northern and north-eastern parts of Greenland (seismic zone 4), the seismic risk is very low, since the only permanent residents are the five Danish Air Force personnel at Station 
Nord and the staff at the Danmarkshavn weather station, where the buildings are designed to withstand the Arctic climate. The next two zones in order of decreasing seismic hazard are the Disko Bugt - Sisimiut area (seismic zone 8) and southern Greenland (seismic zone 1). Larger infrastructure and denser population in seismic zones 1 and 8 indicate that these are judged to be at the highest seismic risk in the whole of Greenland.

\section{Concluding remarks}

The results presented in this study have completely changed the seismic hazard assessment of Greenland compared to the seismic hazard map compiled by GSHAP (Giardini et al. 1999). GSHAP overestimated the seismic hazard of the area north of Disko Bugt and underestimated the seismic hazard for the southern, the northern and the north-eastern parts of Greenland.

During recent years, the majority of reports received by GEUS of earthquakes felt by the resident population are from Tasiilaq (seismic zone 2), but our results show that the seismic hazard in this area is low because these earthquakes are small.

The overall seismic hazard in Greenland is low compared to the many other natural hazards. However, large destructive earthquakes can occur unexpectedly even in areas with low seismicity, as illustrated by the magnitude 6.3 Latur earthquake in central India on 30 September, 1993 (Gupta 1993).

\section{Acknowledgements}

GeoForschungsZentrum (GFZ) Potsdam, Germany, provides instrumentation and technical support to the seismograph in Danmarkshavn and, together with the Incorporated Research Institutions for Seismology (IRIS), USA, to the seismograph in Kangerlussuaq. GFZ has also contributed to the installation and operation of several temporary seismic stations. The Bureau of Minerals and Petroleum, Government of Greenland, provided financial support for several temporary installations.

\section{References}

Atakan, K., Ojeda, A., Camelbeeck, T., \& Meghraoui, M. 2001: Seismic hazard analysis results for the Lower Rhine Graben and the importance of paleoseismic data. Netherlands Journal of Geosciences 80, 305-314.

Chalmers, J.A. \& Pulvertaft, T.C.R. 2001: Development of the continental margins of the Labrador Sea: a review. Geological Society (London) Special Publications 187, 77-105.

Christiansen, F.G., Bojesen-Koefoed, J.A., Chalmers, J.A., Dalhoff, F., Marcussen, C., Nielsen, T., Nøhr-Hansen, H. \& Sønderholm, M. 2002: Petroleum geological activities in West Greenland in 2001. Geology of Greenland Survey Bulletin 191, 57-60.

Dahl-Jensen, T., Larsen, L.M., Pedersen, S.A.S., Pedersen, J., Jepsen, H.F., Pedersen, G., Nielsen, T., Pedersen, A.K., von Platen-Hallermund, F. \& Weng, W. 2004: Landslide and tsunami 21 November 2000 in Paatuut, West Greenland. Natural Hazards 31, 277-287.

Ekström, G., Nettles, M., \& Abers, G.A. 2003: Glacial earthquakes. Science 302, 622-624.

Giardini, D., Grünthal, G., Shedlock, K.M., \& Zhang, P. 1999: The GSHAP global seismic hazard map. Annali di Geofisica 42, 1225-1230.

Gregersen, S. 1982: Seismicity and observations of Lg wave attenuation in Greenland. Tectonophysics 89, 77-93.

Gregersen, S. 2006: Intraplate earthquakes in Scandinavia and Greenland. Neotectonics or postglacial uplift. Journal of Indian Geophysical Union 10, 25-30

Gupta, H.K. 1993. The deadly Latur earthquake. Science 10, 1666-1667. Havskov, J., \& Ottemöller, L. 2003: SEISAN: the earthquake analysis software for Windows, Solaris and Linux, version 8.0, 244 pp. Bergen: Institute of Solid Earth Physics, University of Bergen, Norway.

Jiménez, M.-J., Giardini, D. \& Grünthal, G. 2003: The ESC-SESAME unified hazard model for the European-Mediterranean region, EMSC/CSEM Newsletter 19, 2-4.

Larsen, T.B., Dahl-Jensen, T., Voss, P., Jørgensen, T.M., Gregersen, S. \& Rasmussen, H.P. 2006: Earthquake seismology in Greenland - improved data with multiple applications. Geological Survey of Denmark and Greenland Bulletin 10, 57-60.

Lienert, B.R.E. \& Havskov, J. 1995: A computer program for locating earthquakes both locally and globally. Seismological Research Letters 66, 26-36.

Poulsen, S.K. \& Simonsen, S.B. 2006: Seismic hazard analysis of Greenland and a distribution of earthquakes, 68 pp. Unpublished B.Sc. thesis, University of Copenhagen, Denmark.

Spudich, P. et al. 1997: SEA96 - a new predictive relation for earthquake ground motions in extensional tectonic regimes. Seismological Research Letters $\mathbf{6 8}, 71-79$.

\section{Authors' addresses}

P.V \& S.G., Geological Survey of Denmark and Greenland, Øster Voldgade 10, DK-1350 Copenhagen K, Denmark. E-mail: pv@geus.dk S.K.P. \& S.B.S., Niels Bohr Institute, University of Copenhagen, Juliane Maries Vej 30, DK-2100 Copenhagen Ø, Denmark. 